Discussion Paper No. 12-011

Peer Effects and Academics' Industry Involvement:

The Moderating Role of Age on Professional Imprinting

Birgit Aschhoff and Christoph Grimpe

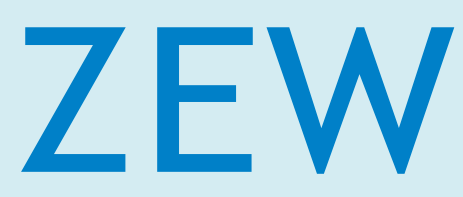

Zentrum für Europäische Wirtschaftsforschung $\mathrm{GmbH}$ Centre for European Economic Research 
Discussion Paper No. 12-011

\title{
Peer Effects and Academics' Industry Involvement: The Moderating Role of Age on Professional Imprinting
}

\author{
Birgit Aschhoff and Christoph Grimpe
}

Download this ZEW Discussion Paper from our ftp server:

http://ftp.zew.de/pub/zew-docs/dp/dp12011.pdf

Die Discussion Papers dienen einer möglichst schnellen Verbreitung von neueren Forschungsarbeiten des ZEW. Die Beiträge liegen in alleiniger Verantwortung der Autoren und stellen nicht notwendigerweise die Meinung des ZEW dar.

Discussion Papers are intended to make results of ZEW research promptly available to other economists in order to encourage discussion and suggestions for revisions. The authors are solely responsible for the contents which do not necessarily represent the opinion of the ZEW. 


\section{Non-technical Summary}

How does social interaction influence an academic's decision to become entrepreneurial and to collaborate with industry? Does the academic's age attenuate or amplify its effects? Since links between science and industry have become a widespread phenomenon over the last decades, a growing body of literature has investigated the role of peers in shaping an academic's engagement in commercial activities. In this paper, we seek to shed more light on the boundary conditions for the effects of social interaction on a scientist's engagement with industry. Specifically, we examine the impact of localized and personal peer effects on academics' involvement with industry and how these effects are moderated by the career age of the scientist. We suggest that both localized and personal peer effects drive industry involvement but that the effects from such imprinting are more pronounced for younger researchers, suggesting that professional imprinting takes place in the early stages of a scientist's academic career.

Our empirical analysis rests upon a sample of 330 academic scientists working in the field of biotechnology in Germany who were surveyed in 2010. The results indicate that Social interaction plays a major role in shaping scientists’ propensity to engage with industry. Both localized and personal peer effects turn out to be relevant which confirms and extends prior literature. Moreover, the scientist's career age turns out to be an important boundary condition, but only for one type of peer effects. While localized peer effects, i.e. the scientist department's co-publications with industry, lead to imprinting particularly in the early years

of a scientist's career, the personal peer effect remains unaffected by the career age. Moreover, for younger researchers the localized peer effect is larger than the personal peer effect. Our results hold important implications for science, technology and innovation policy on how to stimulate academics' engagement with industry. 


\section{Das Wichtigste in Kürze (Summary in German)}

Wie beeinflussen soziale Interaktionen die Entscheidungen von Wissenschaftlern, mit der Industrie zusammen zu arbeiten? Welche Rolle spielt dabei das Alter des Wissenschaftlers für den Entscheidungsprozess? In Zeiten intensiver Zusammenarbeit zwischen Wissenschaft und Wirtschaft widmet sich eine wachsende Anzahl von Studien der Frage, welche Rolle die Kollegen am Arbeitsplatz eines Wissenschaftlers für den Wissens- und Technologietransfer spielen. Die vorliegende Studie will zu diesem Thema einen Beitrag leisten und geht der Frage nach, ob der Einfluss sozialer Interaktion vom Alter des Wissenschaftlers abhängig ist. So wird zwischen „lokalisierten“ und „persönlichen“ Effekten sozialer Interaktion unterschieden. Während erstere den Einfluss der Institution, an der der Wissenschaftler tätig ist, widerspiegeln, fokussieren letztere auf den Einfluss von Ko-Autoren des Wissenschaftlers. Unsere theoretischen Überlegungen vermuten dabei einen positiven Effekt beider Arten sozialer Interaktion auf die Neigung des Wissenschaftlers, mit der Wirtschaft zusammen zu arbeiten. Allerdings gehen wir davon aus, dass beide Effekte umso deutlicher zu Tage treten, je jünger der betreffende Wissenschaftler ist.

Unsere empirische Analyse beruht auf einer Stichprobe von 330 Wissenschaftlern in der Biotechnologie, die im Jahr 2010 befragt wurden. Die Ergebnisse legen nahe, dass soziale Interaktion in der Tat wesentlich für Industriekollaboration verantwortlich ist. Tatsächlich spielt auch das Alter eine wesentliche Rolle: Jüngere Wissenschaftler lassen sich sehr viel mehr von Kollegen beeinflussen als ältere Wissenschaftler. Es stellt sich außerdem heraus, dass für jüngere Wissenschaftler der Effekt der Institution grösser ist als der der Ko-Autoren. Unsere Ergebnisse erlauben eine Reihe von Schlussfolgerungen für die Innovationspolitik, um die Zusammenarbeit zwischen Wissenschaft und Wirtschaft weiter zu stimulieren. 


\title{
Peer effects and academics' industry involvement: The moderating role of age on professional imprinting
}

\author{
Birgit Aschhoff ${ }^{a}$ and Christoph Grimpe ${ }^{b}$ \\ a) Centre for European Economic Research (ZEW), Mannheim (Germany) \\ b) Copenhagen Business School, Copenhagen (Denmark)
}

January 2012

\begin{abstract}
This study explores the interaction between professional imprinting and age in the context of industry-science collaboration. Specifically, we examine the impact of localized and personal peer effects on academics' involvement with industry and how these effects are moderated by the career age of the scientist. We suggest that both localized and personal peer effects drive industry involvement but that the effects from such imprinting are more pronounced for younger researchers, suggesting that professional imprinting takes place in the early stages of a scientist's academic career. Based on a sample of 330 German academics in the field of biotechnology and publication data from the Science Citation Index Expanded (SCIE), we find that scientists with industry-oriented co-authors are more likely to be involved with industry (personal peer effect). Moreover, we find that the scientist's involvement increases with the orientation of the scientist's department towards industry (localized peer effect). Only the latter effect turns out to be moderated by scientist's age. While personal peer effects are independent of the scientist's age, localized peer effects emerge for younger researchers.
\end{abstract}

Keywords: university-industry linkages, professional imprinting, peers, biotechnology JEL-Classification: O31, L30

\section{Contact details:}

Birgit Aschhoff, Centre for European Economic Research (ZEW), Dept. Industrial Economics and International Management, L7 1, 68161 Mannheim, Germany Phone: +49 6211235 182, E-Mail: aschhoff@zew.de

Christoph Grimpe, Copenhagen Business School, Dept. of Innovation and Organizational Economics, Kilevej 14A, 2000 Frederiksberg, Denmark

Phone: +45 3815 2530, E-Mail: christoph@cbs.dk

\section{Acknowledgements:}

Financial support by the STRIKE network is gratefully acknowledged. We thank Christian Rammer as well as the participants of the Second Asia-Pacific Innovation Conference (Singapore, 2011), the 4th ZEW Conference on Economics of Innovation and Patenting (Mannheim, 2011), and the EARIE Conference (Stockholm, 2011) for helpful comments and discussion. 


\section{Introduction}

How does social interaction influence an academic's decision to become entrepreneurial and to collaborate with industry? Does the academic's age attenuate or amplify its effects? Since links between science and industry have become a widespread phenomenon over the last decades (Rothaermel et al., 2007), a growing body of literature has investigated the role of peers in shaping an academic's engagement in commercial activities. In this regard, Stuart and Ding (2006) find that scientists with co-authors who have become academic entrepreneurs are more likely to become commercially active themselves. Bercovitz and Feldman (2008) show that scientists are more likely to disclose their inventions if they observe technology transfer activities among their local peers. Nanda and Sørensen (2010), investigating the effect of workplace peers on entrepreneurial activity, argue that career experiences of co-workers not only influence the individual directly, but that such experiences actually "spill over" to others and thus indirectly influence the transition to entrepreneurial activity.

One line of argument suggests that such spillover effects are due to better information or resources that the scientist's social environment might provide (e.g., Sorensen and Audia, 2000). Another line of argument focuses on reference groups and social norms to explain individual behavior (e.g., Kenney and Goe, 2004; Bercovitz and Feldman, 2008). In a Mertonian view, universities are seen as repositories for the norms of open science, characterized as communalism, universalism, disinterestedness, and organized skepticism (Merton, 1973). Producing and diffusing scientifically valuable knowledge to realize an economic return thus implies a departure from the traditional mission and priority of academia (Dasgupta and David, 1994). In this regard, workplace peers influence the 
informational and normative environment that exerts an effect on the decision to become commercially active.

Despite these insights, less attention has been paid to the contingencies that influence these effects. In this paper, we seek to shed more light on the boundary conditions for the effects of social interaction on a scientist's engagement with industry. Specifically, we suggest that the age of the scientist plays a decisive role for when "professional imprinting" occurs. Professional imprinting refers to a process in which individuals observe the behavior of peers in their environment and tend to imitate or adopt the observed practice like, for example, the industry involvement of colleagues (DiMaggio and Powell, 1983; Bercovitz and Feldman, 2008). In this regard, we draw a distinction between localized and personal peer effects on academics' involvement with industry and how these effects are moderated by the career age of the scientist, i.e. the number of years since the scientist earned his or her PhD. We suggest that a scientist's involvement with industry will increase with the orientation of the scientist's department towards industry, measured by the share of publications in the scientist’s department co-authored with industry personnel (localized peer effect). Moreover, we expect scientists with industry-oriented co-authors, i.e. co-authors who have previously co-authored with industry personnel, to be more likely to become involved with industry (personal peer effect). We expect both effects to be stronger the more recent the vintage of the scientist's $\mathrm{PhD}$, suggesting that professional imprinting takes place in the early stages of a scientist's academic career. Put differently, we assume that more experienced scientists are less susceptible to orientations in their professional environment than younger scientists and that the effects of social interaction are consequently lower.

Our empirical analysis is based on a sample of 330 academic scientists working in the field of biotechnology in Germany who were surveyed in 2010. In fact, one of the industries that is particularly knowledge-driven and close to scientific research is the biotechnology 
industry. Technology for new products, methods and services frequently emerges from scientific institutions or in collaboration between firms and such institutions (e.g., Audretsch and Stephan, 1996; Zucker et al., 2002). Involving researchers from academia tends to be more important in biotechnology than in other sectors (Higgins et al., 2008). Germany has a lively and growing biotechnology scene, involving about 540 dedicated biotech companies as well as about 200 universities and public research institutions that carry out biotechnological research (BIOCOM, 2011).

The results indicate that professional imprinting plays a major role in shaping scientists’ propensity to engage with industry. Both localized and personal peer effects turn out to be relevant, which confirms and extends prior literature (Bercovitz and Feldman, 2008). Moreover, the scientist's career age turns out to be an important boundary condition, but only for one type of peer effects. While localized peer effects, i.e. the scientist's department's co-publications with industry, lead to imprinting particularly in the early years of a scientist's career, the personal peer effect remains unaffected by career age. Moreover, for younger researchers the localized peer effect is larger than the personal peer effect.

We aim to contribute to existing literature in three ways. First, we extend existing studies in the field by disentangling the professional imprinting effect further. We differentiate between the effects that stem from localized (department) and personal (coauthors) peers, allowing us to examine the relative impact of both. Second, the researcher's career age is identified as an important boundary condition for a researcher's "proneness" to imprinting. Third, we do not limit the researcher's commercial activity to a specific type of commercial activity such as the disclosure of an invention. Instead we consider a broader set of industry-science interactions by using an industry involvement index that comprises five different channels of knowledge and technology exchange. In that respect, our research is positioned to further contribute to the body of literature that investigates the factors driving 
academics to engage with industry (e.g., Meyer-Krahmer and Schmoch, 1998; Link et al., 2007).

The remainder of the paper is organized as follows. The next section summarizes the current literature on academic involvement with industry and derives hypotheses. The data, variables and estimation methods are discussed in section 3. The results and concluding remarks appear in sections 4 and 5, respectively.

\section{Academics' involvement with industry}

\subsection{Literature Review}

It has almost become conventional wisdom that knowledge produced in the public sector constitutes an important ingredient of economic growth and technological progress (Jaffe, 1989; Adams, 1990). Close links to academic research have been shown to be beneficial for the innovation performance of firms (Cockburn and Henderson, 1998; Belderbos et al., 2004). Universities and public research organizations are particularly important collaboration partners because of the novelty and sophistication of the knowledge they create (Link et al., 2007). Interacting with public science is attractive from the firm's point of view because inhouse knowledge production through R\&D implies high cost, given the complex and dynamic processes that knowledge creation requires. Universities offer access to basic research, talented people and complementary resources and allow the firm to explore new technological opportunities (Dasgupta and David, 1994). Moreover, firms can hire public scientists to facilitate the transfer of tacit knowledge and to sustain their absorptive capacity for subsequent knowledge and technology transfer activities (Cohen and Levinthal, 1989; Song et al., 2003). Several studies confirm the benefits of interacting with public science for firm performance. Industry-science interaction improves a firm's ability to innovate 
(Arvanitis et al., 2008) and increases the firm's share of sales of innovative products (Belderbos et al., 2004; Aschhoff and Schmidt, 2008).

Scientific knowledge does not, however, automatically spill over to industry. Knowledge and technology transfer relies on the engagement of the individual academic (Bercovitz and Feldman, 2007). Scientists, for example, need to conduct research relevant to industrial application and disclose new knowledge or collaborate with industry. Transfer is thus dependent on the individual's decision to actively participate in industry-science activities through a variety of channels that can be characterized as either formal or informal. Formal involvement is typically based on a patent to be sold or licensed out (Bozeman, 2000; Thursby and Thursby, 2002), collaboration in R\&D (Laursen et al., 2011) or industrial consulting (Jensen et al., 2010), while informal channels of interaction might involve joint publication of research results with industry personnel or informal contacts (Link et al., 2007; Grimpe and Fier, 2010).

A key concern of prior literature has been to investigate why individual scientists are involved with industry. One of the conceptual lenses adopted in this literature is the scientific and technical human capital approach, which recognizes scientific and technical human capital as "individual endowments", tacit and craft knowledge as well as social contacts and networks (e.g., Bozeman and Corley, 2004; Ponomariov and Boardman, 2010). Scientists accumulate scientific and technical human capital with their career age, scientific productivity, hierarchical position and previous successful collaboration with industry (Belkhodja and Landry, 2007). Moreover, scientists who are well connected, i.e. who occupy a central position in professional networks, build up higher scientific and technical human capital as "social capital begets human capital” (Ponomariov and Boardman, 2010: 616). Higher scientific and technical human capital is positively related with higher industry 
involvement because scientists with a high endowment are assumed to possess greater ability to carry out research projects together with industry.

Another conceptual lens focuses on the organizational context, i.e. the characteristics of organizations that influence a scientist's involvement with industry (e.g., Meyer-Krahmer and Schmoch, 1998; Siegel et al., 2003; Siegel et al., 2004). Several studies have shown that industry involvement depends on the mission and institutional context of public scientists, with differences being particularly pronounced between university-affiliated scientists and those at mission-oriented public research institutes. Schmoch et al. (2000) and Heinze and Kuhlmann (2008) find for Germany that scientists at universities and Max Planck institutes, who are by and large more oriented towards basic research, collaborate less actively with industry than scientists at Fraunhofer institutes, who typically conduct application-oriented research and are dependent on industry funding. Ponomariov (2008) finds a negative correlation between the scientific quality of university units and their industry involvement. Furthermore, Siegel et al. (2004) argue that scientists require an appropriately designed reward and incentive system in order to be more actively involved with industry. The higher the royalty payments to the scientist, the higher the scientist's propensity to collaborate with industry (Link and Scott, 2005). Kenney and Goe (2004) find a positive correlation between the encouragement and support of entrepreneurial activities by the institution (social embeddedness) and the corporate involvement by faculty while comparing the engineering and computer science department of two U.S. universities (Berkeley and Stanford). Moreover, there is considerable evidence that scientists from different fields exhibit different industry involvement (Meyer-Krahmer and Schmoch, 1998; Heinze and Kuhlmann, 2008). Finally, the presence of industry close to the university's location increases industry involvement (Audretsch and Stephan, 1996; Laursen et al., 2011). 
A third approach stresses the role of the social context, which refers to co-location and spatial proximity to other scientists as well as professional relationships among them. In those contexts where individuals observe the behavior of other people in their environment, it is likely that they imitate or adopt a certain practice, and hence become professionally imprinted (DiMaggio and Powell, 1983; Bercovitz and Feldman, 2008). Bercovitz and Feldman (2008) find for two medical schools in the U.S. that the individual's decision to actively engage in technology transfer by disclosing an invention is influenced by the disclosing behavior of their local peers. Professional imprinting also takes place during the training phase. Scientists who observe technology transfer activities during their graduate training have a higher probability to be involved in these activities later in their careers (Bercovitz and Feldman, 2008). Co-authors are also part of a scientist's social environment since co-authorship ties go along with regular interaction (Stuart and Ding, 2006). In the following, we will adopt this latter perspective and discuss the role of the social context in shaping a scientist's likelihood to engage with industry. Moreover, we will introduce the scientist's career age as a boundary condition for the effects that the social context will have.

\subsection{Hypotheses}

Professional imprinting effects.

Prior literature suggests that an individual's behavior is shaped by the social environment for several reasons. Organization theory posits that, on the basis of mimetic and isomorphic processes in organizations, one entity adopts another entity's practice by imitating it in the belief that the new practice is beneficial because the other entity succeeds with it (DiMaggio and Powell, 1983; Giuliani et al., 2010). In a similar way, social learning theory argues that individuals follow the behavior of relevant peers if they face uncertainty about norms (Bandura, 1986; Bercovitz and Feldman, 2008). By observing others, individuals draw inferences about the value of certain choices (Sorensen, 2002), expecting that peers will yield 
similar payoffs from the respective activities (Ellison and Fudenberg, 1993). Moreover, colleagues' behavior provides information of accepted and supported practice (Bercovitz and Feldman, 2007). If involvement with industry is common in one's environment, it is perceived by the individual to conform with prevailing norms.

A scientist's environment prominently refers to the organizational subunit to which the individual is attached. University departments, in this regard, are characterized by both spatial and social proximity. Proximity increases the chances to interact with and consequently to learn from others. Such frequent social interaction will presumably provoke knowledge spillovers that in turn shape an individual's behavior (Stuart and Ding, 2006; Bercovitz and Feldman, 2008). We refer to this effect as the localized peer effect. We expect that in an environment characterized by social and spatial proximity scientists observe their peers' industry orientation and act correspondingly. Specifically, a scientist's involvement with industry will be higher the more the scientist's department is oriented towards industry.

Hypothesis 1 . There is a positive relationship between a scientist's involvement with industry and the extent to which the scientist's department is oriented towards industry.

Another type of peer effect stems from social interaction that is not necessarily localized. Besides departmental colleagues, a scientist's co-authors can serve as a reference point. Scientists actively choose whom to collaborate with and will select co-authors they respect and trust, also across institutional boundaries. Co-authorship ties are characterized by frequent interaction (Stuart and Ding, 2006). Indeed, based on the social proximity, knowledge spills over easily, although this can be moderated by the fact that co-authors are spatially distant. Hence, we refer to this effect as the personal peer effect. Similar to the localized peer effect we expect that a scientist's industry involvement is likely to be 
influenced by the behavior of co-authors, such that a co-author's industry orientation will increase the likelihood of a scientist engaging with industry.

Hypothesis 2. There is a positive relationship between a scientist's involvement with industry and the extent to which the scientist's co-authors are oriented towards industry.

The moderating role of age.

Prior literature indicates that industry involvement is likely to vary with the career age of a scientist. Based on the human capital argument, more experienced researchers are likely to possess a higher ability to carry out research projects with industry. They typically have a larger network of researchers, not only in academia but also in industry, compared to researchers at an early stage in their career. Social capital, in this respect, begets human capital. Since experienced scientists have been active in a particular field for a longer time period, more opportunities have arisen for them to interact with industry researchers. Moreover, they have had more chances to learn from other researchers who have successfully engaged in industry collaboration or they know researchers who switched from science to industry. Time in this regard is necessary to build up relationships. In fact, Haeussler and Colyvas (2011) find for life scientists in the UK and Germany a positive effect of a scientist's age on commercialization activities, including consulting, patenting, and founding of a new business.

Industry involvement, however, contradicts traditional academic norms. Bercovitz and Feldman (2008), for example, show that the probability of disclosing an invention decreases with career age for faculty in medical schools in the U.S. They interpret their finding in such a way that younger researchers tend to more readily adopt new technology transfer policies set up by the research institution. This finding is confirmed by a study of the 
wine industry (Giuliani et al., 2010). Other research finds no effect at all. Ponomariov and Boardman (2010) cannot detect a significant association between career age and the number of publications with industrial collaborators. Overall, prior literature is not unambiguous regarding the effect of a researcher's career age on industry involvement.

However, there are clear indications of the role age plays as a moderator for the two types of peer effects. According to social learning theory, researchers tend to follow the behavior of peers when they face uncertainty (Bandura, 1986; Bercovitz and Feldman, 2008). Uncertainties are particularly high for younger researchers. Moreover, younger researchers are probably more open regarding their research agenda and practice. They still have to find and establish "their" place in the research community, and they learn by observing the research practice of others. If industry involvement is practiced by others they might more readily follow and internalize this practice compared to more experienced researchers. Adoption of specific practices is thus more likely in the training and qualification phase of younger researchers. Bercovitz and Feldman (2008) find that researchers who were exposed to pro-commercialization activities during their training phase (measured by the number of patent applications at the individual's graduate institution during the time of their training) are more likely to adopt this practice in their own career. Thus, we expect that researchers in an early stage of their career are more likely to adopt the practice they are exposed to. We suggest that both the localized and the personal peer effect will have a stronger impact on a scientist's industry involvement the more recent the vintage of the scientist's $\mathrm{PhD}$, suggesting that professional imprinting takes place in the early stages of a scientist's academic career.

Hypothesis 3. The relationship between the scientist's involvement with industry and the extent to which the scientist's department is oriented towards industry will be moderated 
by a scientist's career age such that the scientist's industry involvement will increase the lower the career age is.

Hypothesis 4 . The relationship between the scientist's involvement with industry and the extent to which the scientist's co-authors are oriented towards industry will be moderated by a scientist's career age such that the scientist's industry involvement will increase the lower the career age is.

Finally, we expect a differential impact of localized versus personal peer effects on an academic's industry involvement depending on his or her career age. Younger researchers face greater uncertainty about prospects for promotion and tenure (Bercovitz and Feldman, 2008). In addition, they are more dependent on their department, for example in terms of funding because they lack opportunities and knowledge to acquire extramural research grants. As a result, junior faculty members are more eager to conform to the local environment. We might expect that this pressure to conform typically does not exist in social interaction with the scientist's co-authors, since co-authors are self-chosen and do not necessarily have a say in promotion and tenure decisions. Hence, we suggest that for younger scientists localized peer effects will have a higher impact on industry involvement than personal peer effects.

Hypothesis 5. For younger scientists, localized peer effects have a higher impact on industry involvement than personal peer effects. 


\section{Data and Methods}

\subsection{Data}

To analyze the relationship between professional imprinting, age and industry involvement we make use of a unique dataset. In the summer of 2010, the Centre for European Economic Research (ZEW) undertook an online survey of academic researchers working in the field of biotechnology in Germany. The population targeted comprised researchers who worked at either a university or a public research institution and who had published at least one paper in a peer-reviewed journal in the field of biotechnology. Researchers were identified using journal publications from the Science Citation Index Expanded (SCIE) in the field of biotechnology between 2004 and 2008. The comprehensive list of relevant journals was compiled based on the subject categories assigned to each journal. Only authors working at an institution located in Germany were considered. If provided, the email addresses were taken from the publications to contact the researchers. Otherwise, the email addresses were collected manually from the internet, which involved a complex search since only the authors and affiliations located in Germany were known for each publication but not the link between them. In total, we approached 3,360 researchers (gross sample) of whom 458 filled in the questionnaire. After observations with missing values in the variables of interest had been dropped, a net sample of 330 researchers remained for the empirical investigation. Paper and affiliation characteristics of the population as well as the gross and net samples are shown in Table 4 in the appendix. No alarming bias with regard to the representativeness of the sample was detected.

The publication data from the SCIE conveys information not only about the publication activities of the individual researcher between 2004 and 2008 but also about the departmental publication activities through the mentioned affiliations on a publication. After harmonizing the affiliations we constructed a measure for each institution with the number of publications 
from 2004 to 2008 by members of this institution. For universities this measure is on department level; for public research institutions it is on the institution level. The department's or institution's publication record was then linked to the researcher.

Furthermore, we identified patent applications at the European Patent Office (EPO) in which the researcher is named as the inventor. This allows us to construct a patent stock for each researcher. Moreover, we determined the region where the scientist's institution is located to control for the regional environment. To allow for a reasonable size, regions are defined at the district level (NUTS-3) in which the scientist's institution resides plus the immediate neighboring districts. Regional information on GDP per capita and the number of firms was merged using data from the Federal Statistical Office.

\subsection{Variables}

Dependent variable. In order to measure a scientist's involvement with industry, we follow Bozeman and Gaughan (2007), who construct an industry involvement index based on faculty responses to the question of whether they engaged in different types of industry interaction. In our survey, scientists were asked to indicate interaction with respect to five channels: (a) direct collaboration with industry personnel in a joint research project, (b) performing a service (measuring, analyzing, consulting) or creating a technical artifact (bacteria, cell cultures) on behalf of a company, (c) out-licensing of research results to industry, (d) joint publication of research results with industry personnel, and (e) informal contacts with industry personnel. The time frame the scientists were asked to refer to was the last 12 months, i.e. from about mid-2009 to mid-2010. We then calculated the frequency (in $\%)$ of each item's occurrence in the sample and used the inverse as a weight for the corresponding item. Subsequently, we multiplied each type of interaction with its weight and summed up the factors to create a weighted industrial involvement index. As a robustness 
check, we used the total number of different interaction channels without considering their frequency of occurrence in the sample.

Focus variables. To measure the industry orientation of the scientist's peers we use the concept of co-authorship, i.e. joint publication of the respective scientist with industry personnel. Joint publications can be regarded as a successful outcome of collaboration. Coauthorship activities usually involve joint research, include the exchange of tacit knowledge and provide the opportunity for discussions (Cockburn and Henderson, 1998; Zucker et al., 2002). Furthermore, they are observable to third parties. Using co-authorships has the advantage that the measure is objective and relatively easy to obtain for a large sample (Stokes and Hartley, 1989; Katz and Martin, 1997). However, the measure might be inaccurate if authors are listed due to other reasons, e.g. for honorary or funding reasons (Hagstrom, 1965; Katz and Martin, 1997; Cockburn and Henderson, 1998). Despite this limitation, co-authorships have been widely used in the empirical literature, for example to identify collaborators (Zucker et al., 1998), social activity (Stokes and Hartley, 1989) or connectedness between publicly funded scientists and company scientists (Cockburn and Henderson, 1998).

We use three main explanatory variables. The first explanatory variable focuses on the scientist’s localized peers and their orientation towards industry. To construct this measure, we identified all publications listed in the SCIE that were affiliated with the scientist's department or institute and published between 2004 and 2008. We then identified those publications that were co-authored with industry personnel (identified by affiliation with a firm) and calculated the share of those publications in the total number of publications by department members. ${ }^{1}$ The second variable is intended to capture personal peer effects. The

${ }^{1}$ One may argue that a co-author affiliated with a firm could have been a colleague of the academic scientist at the time the paper was written who later switched to industry. However, this is rather unlikely since the period between paper submission and acceptance is relatively short in the field of biotechnology. From the 
co-authors' industry orientation is measured by identifying all publications by the scientist's co-authors between 2004 and 2008. If any of the scientist's co-authors had published a paper together with industry personnel, a dummy variable was created that takes the value of one and zero otherwise. Since the dependent variable refers to 2009 and 2010, both explanatory variables based on publication information are lagged. The third variable refers to the scientist's career age to test the moderating role of age for the two types of peer effects. Career age is defined as the number of years since the scientist received her $\mathrm{PhD}$. This information is available from the survey. As the variable is skewed, we take the natural logarithm of it.

Control variables. We control for several factors that have been shown to be relevant in studies explaining scientists' involvement with industry (e.g., Link et al., 2007). In this respect, we control for the scientist's research productivity in terms of the number of papers published in SCIE journals from 2004 and 2008. Moreover, we add data on the scientist's patent application stock. Due to the skewed distribution we generate a dummy variable indicating whether the scientist had applied for a patent until 2008. ${ }^{2}$ Another indicator of faculty quality is whether a scientist is tenured or not, and we include a respective dummy variable. In order to capture both the size and the overall research productivity of the department, we include the number of publications in SCIE journals from 2004 to 2008 that were achieved by scientists affiliated with the department. Scientific field effects within biotechnology are controlled for by including dummy variables for a research orientation towards life sciences, natural sciences, engineering, and other sciences. Moreover, we use a dummy variable to indicate whether the scientist's research is applied (in contrast to basic research), which is taken from the questionnaire to control for the technological opportunity

list of all relevant journals 13 journals were randomly chosen. For 130 papers published in 2006 and 2007 in the 13 journals, the average time lag was 4.3 months.

${ }^{2}$ We count patent families in order to avoid double-counting of applications made at different patent offices. The year assigned to a patent refers to its priority year. 
of the research. The regressions also control for the scientist's institutional affiliation. We create a dummy variable that takes a value of one if the scientist works at a research-oriented public research institution such as an institute of the Max Planck Society or the Helmholtz Association. Another dummy takes the value of one if the scientist works at an applicationoriented public research institution like an institute of the Fraunhofer Society or the Leibniz Association. University scientists are the largest group in the sample and thus serve as the base category. A few scientists in the sample are affiliated with both a university and a public research institute though. Besides controlling for the scientist's gender by using a dummy variable that takes a value of one for female scientists, we include two measures that are intended to capture the "supply side" of industry-science interaction opportunities. In this regard, we include the GDP per capita (in EUR) in the region where the scientist's institution is located as well as the number of firms in the region in natural logarithm. The idea behind these two control variables is that industry-science interaction tends to be localized (Laursen et al., 2011) and that more opportunities for interaction arise the higher the regional level of economic development. In this context, the region is defined as the district (NUTS-3) in which the scientist's institution resides plus the immediate neighboring districts.

Finally, our research needs to consider the challenges that arise from identification problems in the analysis of social interaction. Prior research has referred to this challenge as the reflection problem (Manski, 1993, 2000; Bercovitz and Feldman, 2008). If the results are not due to endogenous interaction, i.e. the scientist's behavior varies with the behavior of her peers, but due to correlated effects, i.e. scientists behave in the same way simply because they face similar conditions, then the validity of the results becomes questionable. To mitigate the problem that peer effects are in fact driven by unobserved characteristics of the department or the institutional environment and are hence the result of correlated effects, we include a dummy variable indicating whether technology transfer activities in general have a high 
importance in the scientist's area of research. Moreover, the identification problem is alleviated by using the lagged values of peer behavior (Manski, 2000).

Correlations between the explanatory variables are fairly low (see Table 5 in the appendix). In addition, the average variance inflation factor (VIF) equals 1.27. Thus, there is no indication of a multicollinearity problem in the data.

\subsection{Methods}

Our dependent variable is the industry involvement index, which is the weighted sum of the different channels a researcher uses to interact with industry. Thus the variable is a continuous variable subject to left-censoring. It takes a value of 0 , which represents the lower limit, if the researcher is not involved in any of the five channels of industry interaction. The largest value of the variable in the sample is 2.6. Consequently, industry involvement is estimated by applying a tobit model (for details on the model see, e.g., Wooldridge, 2007).

As an alternative dependent variable we use the number of industry interaction channels. The variable takes integer values from 0 , in case of no industry involvement, to 5 , if the researcher is involved in all five types of interaction. Since the variable has an upper limit, a count data model would not be an appropriate estimation method. Instead we use the ordered probit model to take into account the ordinal structure of the variable (Wooldridge, 2007). Moreover, we perform several robustness checks to tackle potential endogeneity and selection issues.

\section{$4 \quad$ Results}

\subsection{Descriptive results}

Table 1 presents descriptive statistics for the variables used in the analysis for the full sample and a split sample, depending on a researcher's above or below median industry involvement 
index. On average eight percent of the publications within a department are co-authored with personnel from industry. Departments of scientists with below-median industry involvement exhibit lower shares than departments of scientists with above-median industry involvement activities. However, based on a one-tailed t-test for this hypothesized variable the difference is only significant on the ten percent level. A positive relationship between scientists' industry involvement and joint publications of their co-authors with industry personnel becomes evident on the basis of the mean comparison between the two groups. Scientists with higher industry involvement activities have statistically more often co-authors who have published jointly with industry personnel than scientists with lower industry involvement activities. Moreover, the descriptive results also indicate that a scientist's industry involvement varies with academic age. We find that the mean of the academic age of scientists with higher industry involvement is statistically larger than the mean for scientists with less industry involvement. While the descriptive results already indicate some support for our theoretical reasoning, a multivariate analysis is required to test the hypotheses. 
Table 1: Sample averages, total and by industry involvement

\begin{tabular}{|c|c|c|c|c|c|c|c|c|}
\hline & \multicolumn{4}{|c|}{$\begin{array}{l}\text { All observations } \\
(\mathrm{N}=330)\end{array}$} & \multicolumn{2}{|c|}{$\begin{array}{c}\text { Below median industry } \\
\text { involvement index } \\
(\mathrm{N}=163)\end{array}$} & \multicolumn{2}{|c|}{$\begin{array}{c}\text { Above median industry } \\
\text { involvement index } \\
(\mathrm{N}=167)\end{array}$} \\
\hline & Mean & Std. Dev. & Min & Max & Mean & Std. Dev. & Mean & Std. Dev. \\
\hline \multicolumn{9}{|l|}{ Dependent variable } \\
\hline Industry involvement index & 0.933 & 0.711 & 0 & 2.617 & 0.321 & 0.274 & 1.529 & 0.452 \\
\hline No. of industry involvement channels & 2.339 & 1.418 & 0 & 5 & 1.098 & 0.747 & 3.551 & 0.674 \\
\hline \multicolumn{9}{|l|}{ Focus variable } \\
\hline Joint publications w/ industry by dept. (share) & 0.080 & 0.071 & 0 & 0.571 & 0.075 & 0.060 & 0.084 & 0.080 \\
\hline Co-authors published w/ industry (d) & 0.561 & 0.497 & 0 & 1 & 0.442 & 0.498 & 0.677 & 0.469 \\
\hline Years since $\mathrm{PhD}(\ln )$ & 2.199 & 1.127 & 0 & 3.932 & 2.073 & 1.130 & 2.321 & 1.113 \\
\hline \multicolumn{9}{|l|}{ Control variable } \\
\hline No. of publications by dept. & 63.797 & 61.651 & 0 & 266 & 65.740 & 62.9571 & 61.901 & 60.479 \\
\hline No. of publications by individual & 3.667 & 4.185 & 1 & 26 & 2.822 & 3.014 & 4.491 & 4.947 \\
\hline Patent application (d) & 0.421 & 0.495 & 0 & 1 & 0.350 & 0.478 & 0.491 & 0.501 \\
\hline Applied research orientation (d) & 0.703 & 0.458 & 0 & 1 & 0.552 & 0.499 & 0.850 & 0.358 \\
\hline Field: Biosciences (biology, medicine) (d) & 0.742 & 0.438 & 0 & 1 & 0.804 & 0.398 & 0.683 & 0.467 \\
\hline Field: Natural Sciences (d) & 0.124 & 0.330 & 0 & 1 & 0.092 & 0.290 & 0.156 & 0.364 \\
\hline Field: Engineering (d) & 0.067 & 0.250 & 0 & 1 & 0.031 & 0.173 & 0.102 & 0.303 \\
\hline Field: Other (d) & 0.067 & 0.250 & 0 & 1 & 0.074 & 0.262 & 0.060 & 0.238 \\
\hline Universities (d) & 0.655 & 0.476 & 0 & 1 & 0.626 & 0.485 & 0.683 & 0.467 \\
\hline Research-oriented public research institution (d) & 0.303 & 0.460 & 0 & 1 & 0.362 & 0.482 & 0.246 & 0.432 \\
\hline Application-oriented public research institution (d) & 0.079 & 0.270 & 0 & 1 & 0.037 & 0.189 & 0.120 & 0.326 \\
\hline Tenured position (d) & 0.551 & 0.498 & 0 & 1 & 0.509 & 0.501 & 0.593 & 0.493 \\
\hline Female (d) & 0.285 & 0.452 & 0 & 1 & 0.337 & 0.474 & 0.234 & 0.424 \\
\hline GDP per capita in region (EUR) & 31.334 & 8.940 & 19.638 & 54.763 & 32.162 & 9.218 & 30.525 & 8.610 \\
\hline No. of plants in region $(\ln )$ & 9.816 & 0.965 & 7.231 & 11.234 & 9.853 & 1.034 & 9.780 & 0.895 \\
\hline High importance of tech. transfer activities (d) & 0.088 & 0.284 & 0 & 1 & 0.031 & 0.173 & 0.144 & 0.352 \\
\hline
\end{tabular}




\subsection{Regression results}

Table 2 shows our main model results. Models 1 and 2 report findings from the tobit regressions, in which the industry involvement index is used as the dependent variable. In the baseline model 1 we find that co-author publications with industry exhibit a positive effect on industry involvement (personal peer effect) while the effect of the share of publications with industry in the scientist's department is not significant (localized peer effect). Model 1 thus finds initial support for hypothesis 2. Looking at the results in model 2, which incorporates the interaction effects, we again find a positive and significant effect of the co-author's publications with industry on industry involvement. Additionally, we find a positive and significant effect of the share of publications with industry in the scientist's department, which also lends support to hypothesis 1 . Regarding the interaction with the career age of the scientist we find a negative and significant interaction for the share of joint publications with industry in the scientist's department but no significant effect of the interaction for co-authors’ publications with industry. The results of the interaction effects hold if the marginal effects of age as a moderating variable on the relationship between the peers and the industry involvement index are considered. ${ }^{3}$ This result supports hypothesis 3 but rejects hypothesis 4 . Models 3 and 4 use the number of different interaction channels with industry as the dependent variable and are consequently estimated by ordered probit regressions. All results turn out to be consistent with models 1 and 2 .

To test hypothesis 5 we split the sample at the median career age (14 years) and re-estimate the regressions for the split sample (see Table 3). For young scientists both peer effects are

\footnotetext{
${ }^{3}$ Marginal effects are calculated based on the approach suggested by Wiersema and Bowen (2009) and Bowen (2010). There is no change in the sign of the moderating effects over its range of variation. The moderating effect for the localized peers calculated at the variable means is -0.880 with a $\mathrm{z}$-statistic value of $-1.83(\mathrm{p}=0.068)$. The moderating effect for the personal peers varies around zero and is mostly insignificant as it is the case for the moderating effect for personal peers at the variable means.
} 
positive and significant (models 5). This also applies to the corresponding marginal effects. ${ }^{4}$ Moreover, when the marginal effects are compared, it turns out that the localized peer effect is in fact larger than the personal peer effect. The results hold when the number of industry involvement channels is used as dependent variable instead of the industry involvement index. These findings provide support for hypothesis 5.

The regression results for the split sample also back up the results for the role of a scientist's career age since for the younger scientists both professional imprinting effects are present while for the older researchers only the personal peer effect becomes apparent.

\footnotetext{
${ }^{4}$ The average marginal effects of localized peers (joint publication w/ industry by dept.) and personal peers (co-authors published w/ industry) on the expected value of the industry involvement index are 1.261 and 0.317, respectively. The corresponding marginal effects at the sample mean are similar (1.294 and 0.325). The marginal effects are calculated following the method presented by Wiersema and Bowen, 2009.
} 
Table 2: Estimation results (coefficients)

\begin{tabular}{|c|c|c|c|c|}
\hline & Model 1 & Model 2 & Model 3 & Model 4 \\
\hline & $\begin{array}{c}\text { Industry } \\
\text { involvement } \\
\text { index } \\
\end{array}$ & $\begin{array}{c}\text { Industry } \\
\text { involvement } \\
\text { index } \\
\end{array}$ & $\begin{array}{c}\text { No. of } \\
\text { industry } \\
\text { involvement } \\
\text { channels } \\
\end{array}$ & $\begin{array}{c}\text { No. of } \\
\text { industry } \\
\text { involvement } \\
\text { channels } \\
\end{array}$ \\
\hline Joint publications w/ industry by dept. (share) & $\begin{array}{c}0.384 \\
(0.541)\end{array}$ & $\begin{array}{c}2.570^{* *} \\
(1.285)\end{array}$ & $\begin{array}{c}0.656 \\
(0.876)\end{array}$ & $\begin{array}{c}4.401^{* *} \\
(2.085)\end{array}$ \\
\hline Int.: joint publ. w/ ind. by dept. * years since PhD & & $\begin{array}{l}-0.978 * \\
(0.526)\end{array}$ & & $\begin{array}{c}-1.679 * * \\
(0.851)\end{array}$ \\
\hline Co-authors published w/ industry (d) & $\begin{array}{c}0.305 * * * \\
(0.083)\end{array}$ & $\begin{array}{l}0.341^{* *} \\
(0.171)\end{array}$ & $\begin{array}{c}0.525 * * * \\
(0.134)\end{array}$ & $\begin{array}{c}0.544^{* *} \\
(0.273)\end{array}$ \\
\hline Int.: co-authors publ. w/ ind. * years since PhD & & $\begin{array}{l}-0.012 \\
(0.070)\end{array}$ & & $\begin{array}{l}-0.000 \\
(0.111)\end{array}$ \\
\hline Years since PhD (ln) & $\begin{array}{c}0.127 * * * \\
(0.042)\end{array}$ & $\begin{array}{c}0.215^{* * *} \\
(0.071)\end{array}$ & $\begin{array}{c}0.220 * * * \\
(0.067)\end{array}$ & $\begin{array}{c}0.360 * * * \\
(0.113)\end{array}$ \\
\hline No. of publications by dept. & $\begin{array}{l}-0.001 \\
(0.001)\end{array}$ & $\begin{array}{l}-0.001 \\
(0.001)\end{array}$ & $\begin{array}{l}-0.001 \\
(0.001)\end{array}$ & $\begin{array}{l}-0.001 \\
(0.001)\end{array}$ \\
\hline No. of publications by individual & $\begin{array}{l}0.018^{*} \\
(0.010)\end{array}$ & $\begin{array}{l}0.018^{*} \\
(0.010)\end{array}$ & $\begin{array}{l}0.027^{*} \\
(0.016)\end{array}$ & $\begin{array}{l}0.029 * \\
(0.016)\end{array}$ \\
\hline Patent application (d) & $\begin{array}{c}0.041 \\
(0.078)\end{array}$ & $\begin{array}{c}0.059 \\
(0.078)\end{array}$ & $\begin{array}{c}0.043 \\
(0.124)\end{array}$ & $\begin{array}{c}0.070 \\
(0.125)\end{array}$ \\
\hline Applied research orientation (d) & $\begin{array}{c}0.498 * * * \\
(0.085)\end{array}$ & $\begin{array}{c}0.494 * * * \\
(0.085)\end{array}$ & $\begin{array}{c}0.798 * * * \\
(0.138)\end{array}$ & $\begin{array}{c}0.798 * * * \\
(0.139)\end{array}$ \\
\hline Field: Natural Sciences (d) & $\begin{array}{c}0.172 \\
(0.115)\end{array}$ & $\begin{array}{c}0.160 \\
(0.114)\end{array}$ & $\begin{array}{c}0.249 \\
(0.183)\end{array}$ & $\begin{array}{c}0.230 \\
(0.184)\end{array}$ \\
\hline Field: Engineering (d) & $\begin{array}{c}0.355^{* *} \\
(0.159)\end{array}$ & $\begin{array}{c}0.361^{* *} \\
(0.159)\end{array}$ & $\begin{array}{c}0.626^{* *} \\
(0.259)\end{array}$ & $\begin{array}{c}0.636 * * \\
(0.261)\end{array}$ \\
\hline Field: Other (d) & $\begin{array}{c}0.048 \\
(0.151)\end{array}$ & $\begin{array}{c}0.070 \\
(0.151)\end{array}$ & $\begin{array}{c}0.104 \\
(0.240)\end{array}$ & $\begin{array}{c}0.141 \\
(0.241)\end{array}$ \\
\hline Research-oriented public research institution (d) & $\begin{array}{l}-0.078 \\
(0.089)\end{array}$ & $\begin{array}{l}-0.066 \\
(0.089)\end{array}$ & $\begin{array}{l}-0.121 \\
(0.141)\end{array}$ & $\begin{array}{l}-0.103 \\
(0.142)\end{array}$ \\
\hline Application-oriented public research institution (d) & $\begin{array}{l}0.272^{*} \\
(0.151)\end{array}$ & $\begin{array}{l}0.273^{*} \\
(0.151)\end{array}$ & $\begin{array}{l}0.457^{*} \\
(0.244)\end{array}$ & $\begin{array}{l}0.460^{*} \\
(0.244)\end{array}$ \\
\hline Tenured position (d) & $\begin{array}{l}-0.004 \\
(0.092)\end{array}$ & $\begin{array}{l}-0.019 \\
(0.092)\end{array}$ & $\begin{array}{l}-0.035 \\
(0.146)\end{array}$ & $\begin{array}{l}-0.058 \\
(0.147)\end{array}$ \\
\hline Female (d) & $\begin{array}{l}-0.084 \\
(0.083)\end{array}$ & $\begin{array}{l}-0.062 \\
(0.084)\end{array}$ & $\begin{array}{l}-0.147 \\
(0.133)\end{array}$ & $\begin{array}{l}-0.111 \\
(0.134)\end{array}$ \\
\hline GDP per capita in region & $\begin{array}{l}-0.004 \\
(0.005)\end{array}$ & $\begin{array}{c}-0.004 \\
(0.005)\end{array}$ & $\begin{array}{c}-0.006 \\
(0.007)\end{array}$ & $\begin{array}{l}-0.006 \\
(0.007)\end{array}$ \\
\hline No. of plants in region (ln) & $\begin{array}{l}-0.017 \\
(0.044)\end{array}$ & $\begin{array}{l}-0.022 \\
(0.044)\end{array}$ & $\begin{array}{l}-0.023 \\
(0.071)\end{array}$ & $\begin{array}{c}-0.031 \\
(0.071)\end{array}$ \\
\hline High importance of tech. transfer activities (d) & $\begin{array}{c}0.390 * * * \\
(0.142)\end{array}$ & $\begin{array}{c}0.377 * * * \\
(0.142)\end{array}$ & $\begin{array}{c}0.608 * * * \\
(0.231)\end{array}$ & $\begin{array}{c}0.594^{* *} \\
(0.231)\end{array}$ \\
\hline Constant & $\begin{array}{c}0.258 \\
(0.415) \\
\end{array}$ & $\begin{array}{c}0.095 \\
(0.429) \\
\end{array}$ & & \\
\hline Pseudo R2 & 0.16 & 0.17 & 0.12 & 0.12 \\
\hline $\mathrm{N}$ & 330 & 330 & 330 & 330 \\
\hline LR/Wald chi2 & 125.426 & 129.092 & 130.158 & 134.171 \\
\hline P-value & 0.000 & 0.000 & 0.000 & 0.000 \\
\hline Log likelihood & -324.071 & -322.238 & -492.460 & -490.454 \\
\hline
\end{tabular}


Table 3: Estimation results for sub-samples (coefficients)

\begin{tabular}{|c|c|c|c|c|}
\hline & \multirow{2}{*}{\multicolumn{2}{|c|}{$\begin{array}{cc}\text { Model } 5 & \text { Model } 6 \\
\text { Industry involvement index }\end{array}$}} & \multirow{2}{*}{\multicolumn{2}{|c|}{$\begin{array}{cc}\text { Model } 7 & \text { Model } 8 \\
\text { No. of industry involvement } \\
\text { channels }\end{array}$}} \\
\hline & & & & \\
\hline & $\begin{array}{l}\text { Below median } \\
\text { career age }\end{array}$ & $\begin{array}{l}\text { Above median } \\
\text { career age }\end{array}$ & $\begin{array}{l}\text { Below median } \\
\text { career age }\end{array}$ & $\begin{array}{l}\text { Above median } \\
\text { career age }\end{array}$ \\
\hline Joint publications w/ industry by dept. (share) & $\begin{array}{c}1.696 * * \\
(0.790)\end{array}$ & $\begin{array}{l}-0.921 \\
(0.801)\end{array}$ & $\begin{array}{c}3.000^{* *} \\
(1.310)\end{array}$ & $\begin{array}{c}-1.514 \\
(1.396)\end{array}$ \\
\hline Co-authors published w/ industry (d) & $\begin{array}{c}0.426 * * * \\
(0.122)\end{array}$ & $\begin{array}{c}0.253^{* *} \\
(0.113)\end{array}$ & $\begin{array}{c}0.681^{* * *} \\
(0.197)\end{array}$ & $\begin{array}{c}0.547 * * * \\
(0.200)\end{array}$ \\
\hline Years since $\mathrm{PhD}(\mathrm{ln})$ & $\begin{array}{c}0.086 \\
(0.061)\end{array}$ & $\begin{array}{c}0.432^{* *} \\
(0.174)\end{array}$ & $\begin{array}{l}0.172^{*} \\
(0.097)\end{array}$ & $\begin{array}{c}0.787 * * \\
(0.308)\end{array}$ \\
\hline No. of publications by dept. & $\begin{array}{c}0.000 \\
(0.001)\end{array}$ & $\begin{array}{l}-0.001 \\
(0.001)\end{array}$ & $\begin{array}{c}0.000 \\
(0.002)\end{array}$ & $\begin{array}{c}-0.003^{* *} \\
(0.002)\end{array}$ \\
\hline No. of publications by individual & $\begin{array}{l}-0.006 \\
(0.021)\end{array}$ & $\begin{array}{l}0.026^{* *} \\
(0.011)\end{array}$ & $\begin{array}{c}0.000 \\
(0.034)\end{array}$ & $\begin{array}{l}0.038 * * \\
(0.019)\end{array}$ \\
\hline Patent application (d) & $\begin{array}{c}0.033 \\
(0.120)\end{array}$ & $\begin{array}{c}0.126 \\
(0.099)\end{array}$ & $\begin{array}{c}0.023 \\
(0.192)\end{array}$ & $\begin{array}{c}0.203 \\
(0.174)\end{array}$ \\
\hline Applied research orientation (d) & $\begin{array}{c}0.331 * * * \\
(0.122)\end{array}$ & $\begin{array}{c}0.614 * * * \\
(0.113)\end{array}$ & $\begin{array}{c}0.528 * * * \\
(0.196)\end{array}$ & $\begin{array}{c}1.109 * * * \\
(0.208)\end{array}$ \\
\hline Field: Natural Sciences (d) & $\begin{array}{c}0.013 \\
(0.163)\end{array}$ & $\begin{array}{c}0.320^{* *} \\
(0.159)\end{array}$ & $\begin{array}{l}-0.007 \\
(0.262)\end{array}$ & $\begin{array}{l}0.542 * \\
(0.281)\end{array}$ \\
\hline Field: Engineering (d) & $\begin{array}{c}0.298 \\
(0.212)\end{array}$ & $\begin{array}{c}0.538 * * \\
(0.236)\end{array}$ & $\begin{array}{c}0.535 \\
(0.341)\end{array}$ & $\begin{array}{l}1.022 * * \\
(0.433)\end{array}$ \\
\hline Field: Other (d) & $\begin{array}{c}0.114 \\
(0.207)\end{array}$ & $\begin{array}{c}0.169 \\
(0.214)\end{array}$ & $\begin{array}{c}0.124 \\
(0.330)\end{array}$ & $\begin{array}{c}0.431 \\
(0.380)\end{array}$ \\
\hline Research-oriented public research institution (d) & $\begin{array}{c}0.041 \\
(0.128)\end{array}$ & $\begin{array}{c}-0.192 \\
(0.118)\end{array}$ & $\begin{array}{c}0.044 \\
(0.205)\end{array}$ & $\begin{array}{l}-0.318 \\
(0.206)\end{array}$ \\
\hline Application-oriented public research institution (d) & $\begin{array}{c}0.162 \\
(0.265)\end{array}$ & $\begin{array}{c}0.218 \\
(0.185)\end{array}$ & $\begin{array}{c}0.173 \\
(0.425)\end{array}$ & $\begin{array}{c}0.456 \\
(0.327)\end{array}$ \\
\hline Tenured position (d) & $\begin{array}{l}-0.083 \\
(0.135)\end{array}$ & $\begin{array}{l}-0.189 \\
(0.143)\end{array}$ & $\begin{array}{l}-0.194 \\
(0.215)\end{array}$ & $\begin{array}{l}-0.239 \\
(0.249)\end{array}$ \\
\hline Female (d) & $\begin{array}{l}-0.076 \\
(0.116)\end{array}$ & $\begin{array}{c}0.011 \\
(0.119)\end{array}$ & $\begin{array}{l}-0.128 \\
(0.186)\end{array}$ & $\begin{array}{l}-0.043 \\
(0.208)\end{array}$ \\
\hline GDP per capita in region & $\begin{array}{l}-0.007 \\
(0.007)\end{array}$ & $\begin{array}{l}-0.001 \\
(0.006)\end{array}$ & $\begin{array}{l}-0.010 \\
(0.011)\end{array}$ & $\begin{array}{l}-0.003 \\
(0.011)\end{array}$ \\
\hline No. of plants in region $(\ln )$ & $\begin{array}{l}-0.105 \\
(0.066)\end{array}$ & $\begin{array}{c}0.023 \\
(0.057)\end{array}$ & $\begin{array}{l}-0.162 \\
(0.106)\end{array}$ & $\begin{array}{c}0.059 \\
(0.100)\end{array}$ \\
\hline High importance of tech. transfer activities (d) & $\begin{array}{c}0.405^{* *} \\
(0.200)\end{array}$ & $\begin{array}{c}0.233 \\
(0.203)\end{array}$ & $\begin{array}{c}0.648^{* *} \\
(0.325)\end{array}$ & $\begin{array}{c}0.371 \\
(0.364)\end{array}$ \\
\hline Constant & $\begin{array}{l}1.171^{*} \\
(0.597)\end{array}$ & $\begin{array}{l}-0.936 \\
(0.733)\end{array}$ & & \\
\hline Pseudo R2 & 0.14 & 0.22 & 0.10 & 0.16 \\
\hline $\mathrm{N}$ & 162 & 168 & 162 & 168 \\
\hline LR/Wald chi2 & 52.155 & 84.551 & 53.574 & 90.574 \\
\hline P-value & 0.000 & 0.000 & 0.000 & 0.000 \\
\hline Log likelihood & -156.847 & -152.265 & -240.166 & -235.582 \\
\hline
\end{tabular}


Our results indicate that professional imprinting plays a major role in shaping scientists' propensity to engage with industry. Both the localized and the personal peer effect turn out to be relevant, which confirms and extends prior literature (Bercovitz and Feldman, 2008). We find evidence that the localized imprinting effect is dependent on the scientist's career age, in that imprinting through the department is particularly effective in the early years of the scientist's career. In contrast to this, the personal peer effect seems unaffected by career age. This suggests that personal peer effects are less sensitive towards the scientist’s professional "lifecycle" and that the scientist's department acts as a major reference point for the scientist's activities in the early years of her or his career. Comparing the two imprinting effects for younger scientists, it turns out that the behavior of the department plays a larger role than the behavior of the scientist's co-authors, i.e. the localized peer effect is larger than the personal peer effect. This is likely due to the greater dependence of younger scientists on the department than on co-authors.

Regarding the control variables, we find consistent effects across all models. The more recent the vintage of the scientist's $\mathrm{PhD}$ degree, the less likely becomes industry involvement. It appears that the number of publications in the department has no significant effect on industry involvement, i.e. a department's focus on academic research (as opposed to technology development), as evidenced by a high publication output, does not contradict industry involvement. In fact, a focus of the scientist on academic research, measured by the total number of publications, has a slightly positive effect on industry involvement. Thus, our results substantiate to a certain extent the findings of Zucker et al. (2002) on the importance of "star scientists" for commercialization. Moreover, we find that scientists whose research is application-oriented exhibit higher industry involvement. We also find that engineering scientists are significantly more engaged with industry while there are no other significant discipline 
effects. Existing literature that documents disciplinary effects is thus confirmed (e.g., Grimpe and Fier, 2010). Prior patent applications of the scientist turn out to have no effect on industry involvement. If the scientist's area of research is characterized by a high importance of technology transfer activities, industry involvement of the scientist is found to be higher. Interestingly, all other control variables seem to be irrelevant for explaining a scientist's involvement with industry. In this respect, we find no effect of tenure or gender. Moreover, our regional control variables, which are intended to capture the local "pool” of collaboration opportunities, turn out to be insignificant, although prior literature had shown that collaboration patterns tend to be localized (e.g., Czarnitzki and Hottenrott, 2009).

\subsection{Robustness tests}

A potential selection bias might arise if staff hiring relies on the applicant's former industry involvement so that resulting departmental effects are not driven by the department's influence but are due to the department's hiring strategy. A selection problem might also arise on the part of a researcher if application-oriented researchers switch to departments with a higher degree of industry involvement. We address this issue by comparing previous patenting activities by researchers who were newly hired in the period from 2006 to 2008 between more and less industry-oriented departments. Previous patenting activities are measured as a dummy variable that takes the value of one if a researcher is listed at least once as an inventor on a patent application that was filed before the year in which the researcher took up employment at the current department. More and less industry-oriented departments are distinguished by a sample split at the median share of the department's joint publications with industry personnel. The share of newly hired researchers with previous patenting activities is around 65 percent for both 
groups of departments. A t-test confirms that there is no significant difference between the two groups of departments. Thus, we can conclude that the results are not driven by a selection.

In addition, our survey results show that researchers rank publishing as the most important task. About 90 percent of the researchers assess publishing as a very important task of researchers; an additional 8 percent rated it as an important task. In contrast to this, commercial activities play only a minor role. Technology transfer is rated by 9 percent (20 percent) of the respondents as a very important (important) task. Patenting activities reach similar values (9 percent very important; 16 percent important). Accordingly, hiring decisions can be assumed to be based on the publication record of the applicant, not on his or her prior industry involvement (see also Bercovitz and Feldman, 2007).

\section{Conclusion}

Our research sheds new light on the factors driving academics to engage with industry. We suggest that professional imprinting plays a major role, which we distinguish into localized and personal peer effects. Moreover, we explicitly account for the scientist's career age and how this affects professional imprinting. Based on a sample of biotechnology scientists in Germany, our results reveal that imprinting in fact depends on the scientist's career age, with younger scientists being more receptive to imprinting that stems from the local environment, i.e. the scientist's department. While imprinting through co-authors, i.e. personal peers, is important to explain industry involvement, the effect does not appear to depend on the scientist's career age. Moreover, for younger researchers the localized peer effect is larger than the personal peer effect. In this respect, we extend existing literature in the field by disentangling the professional imprinting effect into localized (department) and personal (co-authors) peer effects. Moreover, 
prior literature has all too often treated the scientist's age as a control variable and neglected its moderating impact on imprinting. Finally, previous studies have focused on single areas of scientists' involvement with industry. By employing an industry involvement index that integrates different channels of potential collaboration, we provide a more holistic picture of academics' engagement with industry.

Our research, however, needs to acknowledge several limitations. First, our measure for personal peer effects, i.e. an indicator for whether co-authors of the scientist have published together with industry personnel, could be related to the measure for localized peer effects in case the scientist's co-authors work at the same department, although we generally find a very low correlation between the two measures. Moreover, our survey data just represent a crosssection. Ideally, it would be desirable to follow scientists throughout their career in order to make a better informed analysis of how career age affects professional imprinting.

Nevertheless, our research offers important insights for science, technology and innovation (STI) policy making. Given that the traditional mission of public science has shifted in recent years from educating students and conducting (basic) research towards becoming more “entrepreneurial” and engaging with industry (Etzkowitz et al., 2000), our research makes it clear that it is not only the personal motivation of the scientist or the organizational infrastructure (for example, whether or not there is a technology transfer office) that matter for industry involvement; it is also the scientist's immediate environment to which he or she refers when deciding to engage with industry. Efforts to promote industry involvement should therefore not ignore peer effects, which however can be difficult to influence. Policy measures should hence be targeted primarily at groups of researchers and not (only) individual scientists. Moreover, industry involvement has been shown to typically occur in later stages of the career. If STI 
policy aims at extending industry-science linkages, it seems pivotal to facilitate industry-science interaction, particularly for scientists in their early stage of career. As imprinting has turned out to be more effective in those years, STI policy could target researcher groups with a high share of early-stage researchers. Nevertheless, it should be kept in mind that knowledge exchange at an early stage might not unfold its full potential because younger scientists might have accumulated relatively less knowledge that can be used for commercialization compared to more experienced scientists. 


\section{References}

Adams, J.D. (1990), Fundamental Stocks of Knowledge and Productivity Growth, Journal of Political Economy 98, 673-702.

Arvanitis, S., N. Sydow and M. Woerter (2008), Do Specific Forms of University-Industry Knowledge Transfer Have Different Impacts on the Performance of Private Enterprises? An Empirical Analysis Based on Swiss Data, Journal of Technology Transfer 33, 504533.

Aschhoff, B. and T. Schmidt (2008), Empirical Evidence on the Success of R\&D Cooperation Happy Together?, Review of Industrial Organization 33 (1), 41-62.

Audretsch, D.B. and P.E. Stephan (1996), Company-Scientist Locational Links: The Case of Biotechnology, American Economic Review 86 (3), 641-652.

Bandura, A. (1986), Social Foundations of Thought and Action: A Social Cognitive Theory, Englewood Cliffs, NJ.

Belderbos, R., M. Carree and B. Lokshin (2004), Cooperative R\&D and Firm Performance, Research Policy 33, 1477-1492.

Belkhodja, O. and R. Landry (2007), The Triple-Helix Collaboration: Why Do Researchers Collaborate with Industry and the Government? What Are the Factors That Influence the Perceived Barriers?, Scientometrics 70 (2), 301-332.

Bercovitz, J. and M. Feldman (2007), Academic Entrepreneurs and Technology Transfer: Who Participates and Why?, in: Malerba, F. and S. Brusoni (eds.), Perspectives on Innovation, Cambridge, 381-398.

Bercovitz, J. and M. Feldman (2008), Academic Entrepreneurs: Organizational Change at the Individual Level, Organization Science 19 (1), 69-89.

BIOCOM (2011), The German Biotechnology Sector 2011, Berlin.

Bowen, H.P. (2010), Total, Structural and Secondary Moderating Effects in the Tobit Model and Their Computation Using Stata, Discussion Paper Series No. 2010-02, McColl School of Business, Queens University of Charlotte.

Bozeman, B. (2000), Technology Transfer and Public Policy: A Review of Research and Theory, Research Policy 29, 627-655.

Bozeman, B. and E. Corley (2004), Scientists' Collaboration Strategies: Implications for Scientific and Technical Human Capital, Research Policy 33 (4), 599-616.

Bozeman, B. and M. Gaughan (2007), Impacts of Grants and Contracts on Academic Researchers’ Interactions with Industry, Research Policy 36, 694-707.

Cockburn, I.M. and R.M. Henderson (1998), Absorptive Capacity, Coauthoring Behavior, and the Organization of Research in Drug Discovery, The Journal of Industrial Economics 46 (2), 157-182.

Cohen, W.M. and D.A. Levinthal (1989), Innovation and Learning: The Two Faces of R\&D, The Economic Journal 99 (397), 569-596.

Czarnitzki, D. and H. Hottenrott (2009), Are Local Milieus the Key to Innovation Performance?, Journal of Regional Science 49 (1), 81-112.

Dasgupta, P. and P. David (1994), Towards a New Economics of Science, Research Policy 3, 487-521. 
DiMaggio, P.J. and W.W. Powell (1983), The Iron Cage Revisited: Institutional Isomorphism and Collective Rationality in Organizational Fields, American sociological review 48 (2), 147-160.

Ellison, G. and D. Fudenberg (1993), Rules of Thumb for Social Learning, Journal of Political Economy 101 (4), 612-643.

Etzkowitz, H., A. Webster, C. Gebhardt and B.R.C. Terra (2000), The Future of the University and the University of the Future: Evolution of Ivory Tower to Entrepreneurial Paradigm, Resarch Policy 29 (2), 313-330.

Giuliani, E., A. Morrison, C. Pietrobelli and R. Rabellotti (2010), Who Are the Researchers That Are Collaborating with Industry? An Analysis of the Wine Sectors in Chile, South Africa and Italy, Research Policy 39 (6), 748-761.

Grimpe, C. and H. Fier (2010), Informal University Technology Transfer: A Comparison between the United States and Germany, Journal of Technology Transfer 35, 637-650.

Haeussler, C. and J.A. Colyvas (2011), Breaking the Ivory Tower: Academic Entrepreneurship in the Life Sciences in Uk and Germany, Research Policy 40 (1), 41-54.

Hagstrom, W.O. (1965), The Scientific Community, New York.

Heinze, T. and S. Kuhlmann (2008), Across Institutional Boundaries? Research Collaboration in German Public Sector Nanoscience, Research Policy 37 (5), 888-899.

Higgins, M.J., P.E. Stephan and J.G. Thursby (2008), Conveying Quality and Value in Emerging Industries: Star Scientists and the Role of Learning in Biotechnology, NBER Working Paper No. 14602, Cambridge, MA.

Jaffe, A. (1989), Real Effects of Academic Research, American Economic Review 97 (5), 957970.

Jensen, R., J. Thursby and M. Thursby (2010), University-Industry Spillovers, Government Funding, and Industrial Consulting, NBER Working Paper No. 15732, Cambridge, MA.

Katz, J.S. and B.R. Martin (1997), What Is Research Collaboration?, Research Policy 26 (1), 118.

Kenney, M. and W.R. Goe (2004), The Role of Social Embeddedness in Professional Entrepreneurship: A Comparison of Electrical Engineering and Computer Science at Uc Berkeley and Stanford, Resarch Policy 33 (5), 691-707.

Laursen, K., T. Reichstein and A. Salter (2011), Exploring the Effect of Geographical Proximity and University Quality on University-Industry Collaboration in the United Kingdom, Regional Studies 45 (4), 507-523.

Link, A.N. and J.T. Scott (2005), Universities as Partners in U.S. Research Joint Ventures, Research Policy 34, 385-393.

Link, A.N., D.S. Siegel and B. Bozeman (2007), An Empirical Analysis of the Propensity of Academics to Engage in Informal University Technology Transfer, Industrial \& Corporate Change 16 (4), 641-655.

Manski, C.F. (1993), Identification of Endogenous Social Effects: The Reflection Problem, Review of Economic Studies 60 (204), 531-542.

Manski, C.F. (2000), Economic Analysis of Social Interactions, Journal of Economic Perspectives 14 (3), 115-136.

Merton, R.K. (1973), The Normative Structure of Science, in: Merton, R. K. (ed.) The Sociology of Science: Theoretical and Empirical Investigations, Chicago, IL.

Meyer-Krahmer, F. and U. Schmoch (1998), Science-Based Technologies: University-Industry Interactions in Four Fields, Research Policy 27, 835-851. 
Nanda, R. and J.B. Sørensen (2010), Workplace Peers and Entrepreneurship, Management Science 56 (7), 1116-1126.

Ponomariov, B.L. (2008), Effects of University Characteristics on Scientists' Interactions with the Private Sector: An Exploratory Assessment, Journal of Technology Transfer 33, 485503.

Ponomariov, B.L. and P.C. Boardman (2010), Influencing Scientists' Collaboration and Productivity Patterns through New Institutions: University Research Centers and Scientific and Technical Human Capital, Resarch Policy 39, 613-624.

Rothaermel, F.T., S.D. Agung and L. Jiang (2007), University Entrepreneurship: A Taxonomy of the Literature, Industrial \& Corporate Change 16 (4), 691-791.

Schmoch, U., G. Licht and M. Reinhard eds. (2000), Wissens- Und Technologietransfer in Deutschland, Stuttgart.

Siegel, D.S., D. Waldman and A. Link (2003), Assessing the Impact of Organizational Practices on the Relative Productivity of University Technology Transfer Offices: An Exploratory Study, Research Policy 32, 27-48.

Siegel, D.S., D.A. Waldman, L.E. Atwater and A.N. Link (2004), Toward a Model of the Effective Transfer of Scientific Knowledge from Academicians to Practitioners: Qualitative Evidence from the Commercialization of University Technologies, Journal of Engineering and Technology Management 21, 115-142.

Song, J., P. Almeida and G. Wu (2003), Learning-by-Hiring: When Is Mobility More Likely to Facilitate Interfirm Knowledge Transfer?, Management Science 49 (4), 351-365.

Sorensen, A.T. (2002), Social Learning in the Demand for Employer-Sponsored Health Insurance, Baltimore, MD.

Sorensen, O. and P.G. Audia (2000), The Social Structure of Entrepreneurial Activity: Geographic Concentration of Footwear Production in the United States, 1940-1989, American Journal of Sociology 106 (2), 424-461.

Stokes, T.D. and J.A. Hartley (1989), Coauthorship, Social Structure and Influence within Specialties, Social Studies of Science 19 (1), 101-125.

Stuart, T.E. and W.W. Ding (2006), When Do Scientists Become Entrepreneurs? The Social Structural Antecedents of Commercial Activity in the Academic Life Sciences, Americal Journal of Sociology 111 (1), 97-144.

Thursby, J.G. and M.C. Thursby (2002), Who Is Selling the Ivory Tower? Sources of Growth in University Licensing, Management Science 48, 90-104.

Wiersema, M.F. and H.P. Bowen (2009), The Use of Limited Dependent Variable Techniques in Strategy Research: Issues and Methods, Strategic Management Journal 30, 679-692.

Wooldridge, J.M. (2007), Econometric Analysis of Cross Section and Panel Data, Cambridge, MA.

Zucker, L.G., M.R. Darby and J.S. Armstrong (2002), Commercializing Knowledge: University Science, Knowledge Capture, and Firm Performance in Biotechnology, Management Science 48 (1), 138-153.

Zucker, L.G., M.R. Darby and M.B. Brewer (1998), Intellectual Human Capital and the Birth of Us Biotechnology Enterprises, American Economic Review 88 (1), 290-306. 


\section{Appendix}

Table 4: Representativeness of the sample

\begin{tabular}{|c|c|c|c|}
\hline & Population & $\begin{array}{r}\text { Gross } \\
\text { sample } \\
\end{array}$ & $\begin{array}{r}\text { Net } \\
\text { sample }\end{array}$ \\
\hline Basis: Number of unique papers & 6,990 & 5,635 & 1,079 \\
\hline Number of different authors affiliated w/ institution located in Germany (total) & $18,715^{\mathrm{a})}$ & 3,360 & 330 \\
\hline Number of authors per paper (mean) & 5.4 & 5.4 & 6.0 \\
\hline Journal quality: impact factor (mean) & 3.6 & 3.6 & 3.7 \\
\hline Number of affiliations located in Germany (total) & 11,722 & 9,988 & 2,181 \\
\hline Number of affiliations located in Germany per paper (mean) & 1.7 & 1.8 & 2.0 \\
\hline \multicolumn{4}{|l|}{ Affiliations: Type of institutions (in \%): } \\
\hline university & 47.7 & 49.7 & 48.2 \\
\hline public research institution & 26.9 & 27.4 & 33.1 \\
\hline clinic/hospital & 15.3 & 14.5 & 12.8 \\
\hline industry & 10.1 & 8.3 & 5.8 \\
\hline private person & 0.1 & 0.1 & 0.1 \\
\hline Sum & 100.0 & 100.0 & 100.0 \\
\hline
\end{tabular}

Note: a) approximated 
Table 5: Correlation table (330 observations)

\begin{tabular}{|c|c|c|c|c|c|c|c|c|c|c|c|c|c|c|c|c|}
\hline Variable & (1) & $(2)$ & (3) & (4) & (5) & (6) & $(7)$ & (8) & (9) & $(10)$ & $(11)$ & (12) & (13) & (14) & (15) & $(16)$ \\
\hline (1) Joint publications w/ industry by dept. & 1 & & & & & & & & & & & & & & & \\
\hline (2) Co-authors published w/ industry (d) & 0.16 & 1 & & & & & & & & & & & & & & \\
\hline (3) Years since $\mathrm{PhD}(\mathrm{ln})$ & 0.02 & 0.02 & 1 & & & & & & & & & & & & & \\
\hline (4) No. of publications by dept. & 0.08 & 0.22 & 0.05 & 1 & & & & & & & & & & & & \\
\hline (5) No. of publications by individual & 0.05 & 0.37 & 0.24 & 0.12 & 1 & & & & & & & & & & & \\
\hline (6) Patent application (d) & 0.08 & 0.15 & 0.21 & 0.10 & 0.19 & 1 & & & & & & & & & & \\
\hline (7) Applied research orientation (d) & 0.13 & 0.15 & 0.03 & 0.07 & 0.12 & 0.15 & 1 & & & & & & & & & \\
\hline (8) Field: Natural Sciences (d) & 0.04 & 0.04 & 0.01 & -0.12 & -0.03 & -0.06 & -0.02 & 1 & & & & & & & & \\
\hline (9) Field: Engineering (d) & -0.06 & -0.06 & -0.12 & -0.12 & 0.03 & -0.06 & 0.12 & -0.10 & 1 & & & & & & & \\
\hline (10) Field: Other (d) & -0.02 & 0.02 & -0.07 & -0.07 & 0.12 & -0.01 & 0.12 & -0.10 & -0.07 & 1 & & & & & & \\
\hline (11) Research-oriented public resear & -0.08 & -0.01 & -0.10 & 0.35 & 0.05 & 0.01 & -0.09 & -0.03 & -0.04 & -0.10 & 1 & & & & & \\
\hline (12) Application-oriented public research institution (d) & 0.08 & -0.04 & 0.08 & -0.18 & 0.02 & 0.00 & 0.04 & -0.01 & -0.03 & 0.01 & -0.17 & 1 & & & & \\
\hline (13) Tenured position (d) & -0.04 & 0.07 & 0.57 & 0.00 & 0.23 & 0.20 & 0.00 & 0.03 & -0.08 & -0.03 & -0.03 & 0.08 & 1 & & & \\
\hline (14) Female (d) & -0.07 & -0.09 & -0.15 & -0.02 & -0.18 & -0.12 & 0.00 & 0.05 & -0.01 & 0.02 & 0.01 & -0.08 & -0.13 & 1 & & \\
\hline (15) GDP per capita in region & 0.00 & 0.03 & -0.02 & 0.03 & 0.05 & -0.02 & -0.01 & -0.02 & 0.05 & 0.05 & -0.11 & -0.16 & 0.03 & 0.03 & 1 & \\
\hline (16) No. of plar & -0.16 & 0.01 & 0.00 & 0.23 & 0.02 & -0.05 & -0.03 & -0.02 & 0.05 & 0.01 & 0.02 & 0.07 & 0.01 & 0.02 & 0.39 & \\
\hline (17) High importance of tech. transfer activities (d) & -0.02 & 0.06 & -0.04 & 0.00 & -0.03 & 0.02 & 0.13 & 0.11 & 0.26 & 0.05 & -0.06 & 0.27 & 0.00 & -0.01 & 0.01 & 0.14 \\
\hline
\end{tabular}

